\title{
STICHTINGEN EN FONDSEN IN DE WEST
}

\author{
DOOR
}

FRED. OUDSCHANS DENTZ

Het aantal stichtingen in Suriname vindt men nergens vastgelegd. De gegevens zijn hier en daar verspreid terug te vinden en voor ieder nog niet gemakkelijk bereikbaar. Het leek ons nuttig de geschiedenis van de ons bekende stichtingen in een overzicht vast te leggen. Daarbij hebben wij tevens gevoegd een overzicht van Fondsen, welke bestaan hebben en nog bestaan, voorzoover ons bekend. De lijst zal wel onvolledig zijn, maar wij houden ons voor aanvulling aanbevolen. Het begin is althans gemaakt.

Wij hebben niet alleen aan de Stichtingen en Fondsen in Suriname gedacht, maar eveneens aan die in Curaçao, waarvan wij het bestaan kenden. Bovendien is gewag gemaakt van een Fonds in Britsch Guyana bestaande, dat genoemd is naar een ingezetene, die in Demerara overleed in den Nederlandschen tijd.

Wat de Fondsen betreft meenden wij zoowel die te moeten vermelden welke in als voor Suriname en Curaçao zijn opgericht.

SURINAME.

A. Stichtingen. Voor zoover ons bekend zijn er in Suriname 4 Stichtingen, t.w.

a. De Luchmonsing-Stichting.

b. De Gouverneur-van-Heemstra-Stichting.

c. De Vereeniging voor kindervoeding Dr. Corsten-Stichting.

d. Het Kinderhuis te Saron, Stichting van de Zending der Evangelische Broedergemeente.

a. De Luchmonsing Stichting. Deze stichting werd in het leven geroepen door Mej. Bagessuri No. 608/R bij akte, verleden voor den notaris J. A. Drielsma te Paramaribo op 3 Juni 1924, in welke akte zij, als de eenige erfgename van wijlen Luchmonsing, ten behoeve van voormelde stichting afstand heeft gedaan van het 
pand met de daarop staande gebouwen, gelegen te Paramaribo aan den Waterkant en bekend onder La A No. 223.

Het doel van de stichting is het bestemmen van voormeld pand voor de navolgende doeleinden:

ten eerste als vergaderlokaal van de „Surinaamsche Immigranten Vereeniging", gevestigd te Paramaribo;

ten tweede: voor huisvesting van de in Suriname aangekomen en vertoevende Britsch-Indiërs of hunne nakomelingen ${ }^{1}$ ), hetzij behoeftig of niet, volgens de regelen bij Huishoudelijk Reglement vast te stellen;

ten derde: voor andere doeleinden ten nutte van de BritschIndische bevolking en hare nakomelingen door het Bestuur dezer stichting te bepalen.

Voorzitter van de meerbedoelde stichting is de Britsch-Indiër Rampersad Sukul No. 527/VR., wonende in de Jodenbreestraat te Paramaribo.

De Luchmonsingstichting behoefde geen goedkeuring van den gouverneur op hare statuten en heeft ze daarom niet gevraagd. Zij zijn harerzijds niet openbaar gemaakt. Vorenstaande gegevens danken wij aan de welwillende mededeeling van den gouvernements-secretaris.

b. De Gouverneur-van-Heemstra-Stichting. Deze dagteekent van 27 Maart 1928. Ter gelegenheid van het nederleggen van zijn ambt heeft de Surinaamsche bevolking aan den gouverneur mr.

$\left.{ }^{1}\right)$ Meer dan een halve eeuw hebben Mohamedanen en Hindoes in Suriname naast elkander geleefd. Een sterk bewijs, hoe goed de verstandhouding was, levert deze Stichting. Wijlen Luchmonsing was een Hindoe, maar het was zijn uitdrukkelijk verlangen, dat het door hem na te laten Tehuis aan zijn rasgenooten, zoowel Mohamedanen als Hindoes, ten goede zou komen. Zeker kon hij niet vermoeden, dat later de verstandhouding zoo heel anders zou worden. Er is nl. den laatsten tijd een geschil gerezen in den boezem van de vereeniging Bahrat Oeday, dat in den grond neerkomt op een strijd tusschen Hindoes en Mohamedanen om de supprematie in deze vereeniging en om het beheer der bovengenoemde stichting. Toen in verband met den schoolstrijd de werkzaamheden van het bestuur dier vereeniging toenamen, werd op initiatief van Rampersad, nu wijlen, het bestuur van 9 tot 15 leden uitgebreid. Van dat oogenblik af ontstond de wrijving, waarbij de twee richtingen elkaar den voorrang betwistten. Die strijd liep zóó hoog, dat, toen in verband met het overlijden van Rampersad een vergadering der vereeniging werd aangekondigd, een deel der bestuursleden de rechterlijke tusschenkomst inriep om het huidige bestuur onwettig te verklaren en de vergadering te verbieden. Deze eisch werd afgewezen. De vergadering heeft plaats gehad en in plaats van Rampersad is de heer Ragoobarsing tot voorzitter gekozen. 
Arnoud Jan Anne Aleid baron van Heemstra een huldeblijk aangeboden als uiting zoowel van hare welgemeende gevoelens van oprechte dankbaarheid voor en waardeering van het onverdroten streven van genoemden gouverneur om Suriname uit zijn verval op te heffen en diens nimmer verflauwende toewijding aan de belangen van het Land als van hare sympathie voor zijn persoonlijkheid. Dit huldeblijk bestond uit een som van $f$ 13.500. De commissie welke zich met de inzameling heeft belast bestond uit de heeren: mr. A. L. Nysingh, procureur-generaal bij het Hof van Justitie en ondervoorzitter van den Raad van Bestuur, mr. A. A. van Traa, directeur-voorzitter van De Surinaamsche Bank, J. A. Drielsma, notaris, voorzitter van de Koloniale Staten, H. J. de Vries, koopman, J. S. Abendanon, J. E. Herrenberg en L. E. Nelson, allen ambtenaren. Overeenkomstig de op de lijsten van inteekening voor bedoelde bijdragen aangegeven wijze van bestemming van de voor het huldeblijk ingekomen gelden en met toestemming van gouverneur Van Heemstra heeft de commissie ter eere van en ter voortdurende herinnering aan het gouverneursschap van mr. A. J. A. A. baron van Heemstra een stichting in het leven geroepen met het oogmerk een bestemming van blijvenden aard te bereiken ten bate der lijdende menschheid ten doel hebbende de bevordering der bestrijding van in Suriname inheemsche volksziekten en het geheele kapitaal tot vermogen der stichting bestemd.

De Gouverneur-van-Heemstra-Stichting, waarvan de akte op 27 Maart 1928 voor notaris A. Th. de Miranda is verleden, is te Paramaribo gevestigd en staat onder beschermheerschap van mr. A. J. A. A. baron van Heemstra.

Het doel der stichting wordt omschreven als volgt: de bevordering in den ruimsten zin des woords der bestrijding van in Suriname inheemsche volksziekten, zooals door het uitloven en beschikbaar stellen van prijzen voor de oplossing van prijsvragen op het gebied dier ziekten en of hare bestrijding door haar uit te schrijven, het financieel steunen van wetenschappelijke onderzoekingen en studiën op dit gebied, het ,propageeren" en aanmoediging van de toepassing van hygienische maatregelen als anderszins.

Indien het doel der stichting, waarvan men begunstiger of donateur kan worden, is bereikt of vervallen, dan wel de werking van de vastgestelde bepalingen aangaande het doel moet geacht worden niet meer te beantwoorden aan het oogmerk waarmede zij in het leven is geroepen, zoomede bij blijvende onmogelijkheid 
van samenstelling van een volledig bestuur, een en ander ter beoordeeling van den gouverneur, houdt de stichting op te bestaan en wordt het gebruik van hare bezittingen en inkomsten tot een ander aan de oorspronkelijk beoogde zoo nabij mogelijk komende bestemming geregeld door den gouverneur, den Raad van Bestuur gehoord.

De eerste daad van de stichting is geweest het uitschrijven op den 1sten December 1928 van een prijsvraag, welke beoogde de samenstelling van een lees-leerboekje voor de hoogere klassen van de lagere scholen in Suriname, handelende over de voornaamste en meest voorkomende volks- en besmettelijke ziekten in Suriname. Hiervoor werd een eerste prijsuitgeloofd van $f 250$. - met een groote zilveren medaille en een tweede prijs van $f 100$.met een kleine zilveren medaille.

Er kwamen drie antwoorden in. Aan de inzending: Op hoop van zegen werd de eerste prijs toegekend. Inzender was Rob Simons, medisch student te Paramaribo. De beide andere inzendingen zijn niet voor toekenning van een prijs in aanmerking gekomen. De toekenning van den prijs had plaats in de vergadering van het bestuur der stichting van 6 Augustus.

De bekendmaking van de toekenning van den prijs geschiedde in het G.A.B. van 8 Augustus 1930 no. 66.

Voorts werden met toestemming van het Bestuur weldadigheidspostzegels uitgegeven in 1928, waarvan de termijn van verkrijgbaarstelling tot 30 Juni 1929 werd verlengd, welke als frankeerzegels konden worden gebruikt. Zij bestonden in vier waarden en waren voorzien van het opschrift: Gouverneur van Heemstra Stichting. De zegels van $11 / 2$ cent werden verkocht voor 3 , die van 2 cent voor 4 , die van 5 cent voor 8 en die van 7 cent voor 10 cent.

c. Op 20 Augustus 1928 werd op aanstichting van dr. Frits Corsten, die in December van het jaar daarna (1929) overleed, een comité opgericht met de bedoeling om op de lagere school te $\mathrm{Pa}-$ ramaribo aan behoeftige schoolkinderen melk te verstrekken. Het comité had zijn inkomsten uit vrijwillige bijdragen, en door voortdurende propaganda is het in staat geweest zijn liefdevolle arbeid voort te zetten. In een algemeene vergadering op 26 September 1930 werd besloten het comité voor melkverschaffing in een vereeniging om te zetten, die de naam zou dragen: „Vereeniging voor kindervoeding Dr. Corsten Stichting", welke te Paramaribo gevestigd werd. Was het vroegere comité gehouden om melk te verstrekken, de nieuwe vereeniging heeft haar taak ruimer opgevat. Het doel is thans aan behoeftige schoolkinderen te Paramaribo in 
de voeding tegemoet te komen. Het aantal bedeelden bedraagt thans 600 .

De vereeniging tracht dit doel te bereiken door het onderzoeken in hoeverre ondervoeding bij schoolkinderen voorkomt en welke gevolgen deze heeft voor het onderwijs, het vestigen van de aandacht der Overheid en van particulieren op dit verschijnsel, het verstrekken van voeding aan behoeftige schoolkinderen, de samenwerking te bevorderen tusschen medische- en onderwijskrachten in verband met vorengenoemde ondervinding, en het inzamelen van gelden ter bestrijding van de aan haar arbeid verbonden kosten. De statuten der vereeniging werden bij resolutie van 16 Januari 1931 no. 194 goedgekeurd en afgekondigd in het G.A.B.

d. Het Kinderhuis te Saron. Op 27 September 1910 stichtte de Evangelische Broedergemeente een kinderhuis te Paramaribo hetwelk op 7 December 1911 naar Saron nabij Paramaribo werd verplaatst. Reeds tientallen jaren vóór de stichting waren de zendelingen levendig van de noodzakelijkheid doordrongen om een inrichting in het leven te roepen, waarin kinderen, wier opvoeding in een gesticht wenschelijk geacht werd, opgenomen zouden kunnen worden. Het toenemend gevaar van verwaarloozing der kinderen was een gevaar voor de geheele Surinaamsche samenleving geworden, waarvan zich de bedenkelijke gevolgen in zedelijk, economisch en crimineel opzicht boe langer hoe meer deden gevoelen.

Het was aan het initiatief van Mevrouw M. Müller-Schmidt te danken, dat er in Maart 1910 een comité gevormd werd met het doel de voorbereidende werkzaamheden ter hand te nemen. Hierin zaten de Hoofdvoorstander R. Vouillaire en de zendelingkoopman G. A. Glitsch, alsmede de dames F. H. Schmiedeke, Hasewinkel en Berthold. Aan dit comité werden nog de heer en mevrouw Eckhardt verbonden. Toen het comité de noodige gelden verzameld had werd een diakonesse, zuster Hanna Kunz beroepen, die te voren in het kinderhuis te Zeist en het diakonessenmoederhuis „Emmaus” te Niesky (Duitschland) werkzaam was geweest. Het eerste kind werd op 27 Sept. 1910 opgenomen.

Het eigen tehuis was op de nederzetting Saron bij Beekhuizen aan den spoorbaan gelegen, waar een der oudste gemeenten van de Herrnhutters (sedert 1843) bestond. De inwijding van dit Tehuis had op 7 December 1911 plaats. De toeneming van het aantal kinderen was aanleiding tot het bouwen van een tweede huis, een geschenk van de firma C. Kersten \& Co., ter gelegenheid van haar 150-jarig bestaan, welk groepenhuis uitsluitend voor meisjes was 
bestemd. Het werd op 13 November 1919 ingewijd. In 1913 had het Kinderhuis te Saron, Stichting der Evangelische Broedergemeente in Suriname, opgericht bij akte van 13 Maart rechtspersoonlijkheid gekregen. Zelfs was een derde huis op 13 Augustus 1919 ingewijd ten behoeve van grootere jongens en een vierde Groephuis op 10 Juni 1926 voor meisjes, die de school verlaten hadden. Het doel der stichting is de lichamelijke en geestelijke duurzame verzorging van minderjarigen van alle gezindten, in de eerste plaats van kinderen van de Evangelische Broedergemeente. De Stichting is ontstaan als een heel zelfstandig liefdewerk, dat in zijn eigen kosten voorziet, maar ook door de Overheid geldelijk wordt gesteund en staat onder toezicht van het Provinciaal Bestuur der E.B.G. in Suriname en in laatste instantie onder haar hoofdbestuur te Zeist.

De statuten der Stichting werden in 1910 ingetrokken en vervangen door nieuwe, vastgesteld bij akte van 9 October 1930, welke in het G.A.B. van 28 October van dat jaar no 89 werden gepubliceerd.

B. Fondsen.

a. Jubileumfonds der Evangelische Broedergemeente.

b. Pensioenfonds der W. I. Ambtenaren.

c. Dorcas.

d. Surinamefilmfonds.

e. Fonds tot Herstel van de Kerkruïne met daarbij behoorende Begraafplaatsen op de Joden Savanne.

f. Ondersteuningsfonds van de Vereeniging ,,Suriname”.

g. Fonds van het Surinaamsche Steuncomité.

a. Het Jubileumfonds der Evangelische Broedergemeente. Op den dag, waarop het 50 jaren geleden was, dat de slavernij in Suriname werd afgeschaft, nl. 1 Juli 1913 (de z.g. emancipatie), werd dit fonds opgericht.

Het doel is een eigen begraafplaats aan te schaffen en te onderhouden, hulp te verleenen in ziektegevallen en bij sterfgevallen, lijkpenningen uit te keeren en het betalen der kerkcontributie te vergemakkelijken. Het fonds is te Paramaribo gevestigd en wordt door een centraal bestuur beheerd. Alleen leden der Evangelische Broedergemeente worden als leden toegelaten. Afdeelingsbesturen bestaan in de verschillende stadskerken van Paramaribo.

Het Jubileumfonds bestaat uit een ziekenfonds en een begrafenisfonds. Het Fonds staat geldelijk sterk en heeft een flink reservefonds gevormd.

b. Pensioenfonds der W.I. Ambtenaren. In 1818 sprak Koning 
Willem I den wensch uit ,het lot van uitgediende of aan lighaamsgebreken onderhevige Ambtenaren in de West-Indische Koloniën, benevens derzelver Weduwen en Weezen" te verzekeren door het oprichten van pensioenfondsen in die koloniën.

Er werd voor alle W.I. koloniën tezamen een fonds gevormd (K.B. van 21 Aug. 1818, no. 86) waarvan de hoofdadministratie in Nederland zou worden gevoerd door commissarissen voor de afdeeling W.I. zaken van de Directie der Koloniën, bijgestaan door een amanuensis als kassier. Toen het Fonds geheel onvoldoende bleek, werd bij K.B. van 7 Oct. 1848, no. 72 een geheel nieuw reglement vastgesteld, waarbij bepaald werd, dat de pensioenen, die nu ten laste kwamen van de koloniale kas, verlaagd en de kortingen verhoogd werden. Tevens werd bepaald, dat het ten name van het West-Indische pensioenfonds op de Grootboeken ingeschreven kapitaal zou worden overgeschreven ten name van het Departement van Koloniën, ten einde de rente te doen strekken als subsidie der burgerlijke pensioenen. Het reglement bleef met eenige wijzigingen van kracht tot 1888 , toen een nieuwe pensioenregeling werd gemaakt. Voor Curaçao werden regelingen getroffen in 1868, 1886 en 1899.

Van het kapitaal waren in 1899 aanwezig $f 614.000$ waarvan gerekend werd te behooren aan Suriname $2 / 3$ en aan Curaçao $1 / 3$.

Op voorstel van den Minister van Koloniën werd bij K.B. van 26 Februari 1900 no. 118, machtiging verleend het aan Suriname toekomende deel te gelde te maken, naar gelang er behoefte aan fondsen zou ontstaan tot uitvoering van productieve werken. Voor Curaçao werd een soortgelijke machtiging verleend bij K.B. van 1 April 1903 no. 42. De inschrijvingen werden achtereenvolgens te gelde gemaakt, zoodat er thans niets meer van over is.

Dertig jaren later zou men weer tot het oorspronkelijk plan terugkeeren, nl. de stichting van een pensioenfonds. In de Nota van Wijzigingen, op 19 April gedagteekend, behoorende bij de Koloniale Huishoudelijke Begrooting voor het dienstjaar 1931, Bijlagen 1929-1930 (25. 17.) lezen wij bij g: Na artikel 190 wordt het volgende nieuwe artikel 190bis opgenomen: „Stortingen in het pensioenfonds.... Memorie". De toelichting daarbij luidde:

Het overleg met het Opperbestuur over de instelling van een pensioenfonds is zoover gevorderd, dat de Minister van Koloniën den wensch heeft te kennen gegeven reeds nu een grondslag te leggen voor het bij afzonderlijke wet in te stellen pensioenfonds door in de begrooting voor 1931 - tot het uitdrukken van het beginsel - een post op te nemen voor stortingen in het pensioenfonds. 
De bedoeling van dezen memoriepost is dus den begrootingswetgever zich in beginsel te doen uitspreken, dat de stichting van een zelfstandig pensioenfonds gewenscht wordt en tevens de mogelijkheid te openen daarvoor in 1931 reeds gelden te reserveeren.

Voor dit laatste is te meer aanleiding, nu binnenkort een ontwerp voor een nieuwe pensioenverordening bij de koloniale staten zal worden ingediend, waarvan wellicht reeds in 1931 eene stijging van den post voor inhoudingen en stortingen voor pensioen het gevolg zal zijn. In dat geval is het gewenscht deze stijging niet voor de gewone uitgaven te besteden, maar deze van den aanvang af te reserveeren voor het in te stellen pensioenfonds, waarvan de opbouw gedurende de eerste jaren onvermijdelijk hoogere financieele eischen aan 's lands kas zal stellen.

Omdat de wet tot instellen van een pensioenfonds nog niet is tot stand gekomen, is ook op de koloniale huishoudelijke begrooting voor 1933 de post andermaal voor Memorie uitgetrokken.

c. Aan de stichting van het Fonds „Dorcas” ten behoeve van een Hervormde-Luthersche Weezen Stichting ging het volgende vooraf.

In 1867 besloot de kerkeraad van de Hervormde Gemeente te Paramaribo een commissie van 4 leden te benoemen onder voorzitterschap van ds. S. van Dissel om een plan te maken voor de stichting van een weeshuis, waaraan toen groote behoefte bestond. De zaak bleef rusten, omdat de commissie den kerkeraad adviseerde het plan om de daaraan verbonden geldelijke bezwaren op te geven. Toen evenwel ds. C. Conradi in 1870 van een onbekende een bedrag ontving van $f$ 100.- voor het oprichten van een weeshuis, zoowel van kinderen van de Hervormde als van de Luthersche gemeente, werd er andermaal een commissie ad hoc benoemd die den Lutherschen kerkeraad uitnoodigde eveneens een commissie te benoemen om gemeenschappelijk te beraadslagen. Deze commissies konden niet tot overeenstemming komen, omdat de Luthersche kerkeraad de stichting van een algemeen weeshuis voorstond, waarin ook Israelietische kinderen zouden worden opgenomen. Beide commissies zijn toen op zich zelf gaan werken. Daarop besloot de Hervormde gemeente een fonds aan te leggen, waaruit later een weeshuis zou worden gesticht, dat ook voor Luthersche kinderen toegankelijk zou zijn. De gouverneur zegde zijn medewerking toe. In 1872 werden voor dat doel circulaires uitgezonden, zoowel naar Nederland als in Suriname zelf. In de Surinaamsche Almanak van 1888 wordt als voorzitter van de Hervormde-Luthersche Weezenstichting dr. G. C. Steynis (van de Luthersche gemeente) genoemd en E. A. Cabell (notaris) als 
secretaris. In 1889 wordt J. F. A. Cateau van Rosevelt als vicevoorzitter en W. van Esveld, de Directeur-Voorzitter der Surinaamsche Bank, als penningmeester opgegeven. De laatste nam die functie vele jaren waar. Door de stuwkracht van dr. Zaalberg kwamen de gelden binnen en in de Surinaamsche Almanakken zien wij geregeld een overzicht van den stand van het Fonds, dat "Dorcas" werd geheeten. Het geld was in Nederland belegd in Certificaten N.W.S. en groeide voortdurend aan. De laatst ingekomen gift was van mr. A. C. Wesenhagen te Rotterdam op 26 Juli 1896 groot $f 15,71$. Ten slotte werd bij akte van 30 December 1907 ten overstaan van notaris I. da Costa door ds. H. Buiskool (van de Hervormde Gemeente) en P. A. Bruggeman (van de Luthersche Gemeente) een stichting voor de gezamenlijke weezen opgericht, geheeten :Stichting Doorgangshuis voor de Hervormde Luthersche Weezen. Bij akte van denzelfden datum verklaren A. Conradi, A. S. J. Fernandes, qq. A. van 't Hoogerhuis, dat aan ds. H. H. Zaalberg te Amsterdam (niet te verwarren met dr. Zaalberg) machtiging is verleend om van de Hoofddirectie der Surinaamsche Bank de door het comité bij die Bank belegde gelden en effecten op te vorderen, hetgeen is geschied. Ds. Zaalberg nam alles onder zijn beheer.

Deze gelden zijn weer overgenomen door het Bestuur van de stichting, nl. ds. H. Buiskool, J. H. Wijngaarde, A. A. Heckers, (voor de Herv. Gemeente) en A. G. Putscher en F. C. Curiel (voor de Luth. Gemeente). Voor de overneming had een vergadering plaats van beide kerkeraden ten overstaan van de heeren mr. Heylidy, W. van Esveld, A. Terlaag en W. L. Loth. De heer Heckers was secretaris, de heer Putscher penningmeester. Men slaagde er niet in aan het fonds een bestemming te geven. Het werd door den heer Putscher op hypotheken uitgezet toen het ongeveer $f 14000$ bedroeg. Na 14 jaren nauwgezet beheer verdubbelde het tot $f 28000$. In overleg der beide kerkeraden is in 1921 op voorstel van den heer Putscher aan ds. Poort van de Hervormde Gemeente, de beschikbare som verdeeld, zoodanig, dat de Hervormde gemeente $2 / 3$ en de Luthersche Gemeente $1 / 3$ daarvan heeft ontvangen, overeenkomstig een bepaling in de statuten.

De Hervormde gemeente heeft haar uitgekeerd aandeel besteed om rond de Kerk een ijzeren hek te plaatsen op het toen verbeterde Kerkplein, zoodat de Kerk binnen een afgesloten ruimte kwam te staan.

De Evang. Luthersche gemeente kocht voor haar aandeel een huis aan de Maagdenstraat, van achter grenzende aan het erf, waarop de Kerk staat. 
d. Surinamefilmfonds. In 1922 werd in Suriname een rolprent van het land opgenomen. De kosten daarvan schoot de gouverneur van Suriname, mr. A. J. A. A. baron van Heemstra voor. Een comité in Suriname, verschillende vereenigingen vertegenwoordigend, bracht een groot bedrag bijeen uit inzamelingen in Suriname, Nederland en Ned.-Indië om de som bijeen te krijgen, welke de gouverneur had voorgeschoten. Maar de kosten werden bij lange na niet gedekt.

Op den 2den Maart 1922 sloot de gouverneur, in dezen vertegenwoordigd door den gouvernements-secretaris mr. dr. P. H. W. G. van den Helm, met het bestuur van groep Suriname van het Algemeen Nederlandsch Verbond een overeenkomst, waarbij hij zich verbond, indien en zoodra door den filmoperateur Fouquet te Parijs een Surinamefilm (negatief en daarvan afgedrukte positieven tot een maximum van vijf) zal zijn geleverd, die film in eigendom over te dragen aan het Bestuur van de Groep Suriname van het A.N.V., onder opgave van de kosten en van hetgeen door hem ter dekking van die kosten ontvangen is of zal worden.

Daartegenover verbond zich het A.N.V.

$a$. den eigendom van genoemden film te aanvaarden.

$b$. de film te doen exploiteeren, bij voorrang in Nederland.

$c$. uit de zuivere opbrengst dier exploitatie om uit de met name ten behoeve der film aan het Bestuur voornoemd ter hand gestelde gelden, aan den geldschieter te vergoeden de kosten van verkrijging der film, voorzoover deze kosten niet reeds gedekt waren uit de zuivere opbrengst van de door het filmcomité te Paramaribo gehouden inzameling.

$d$. na algeheele vergoeding der bovenbedoelde kosten het mogelijk overschot van de zuivere opbrengst der exploitatie uitsluitend te besteden voor het bekostigen van maatregelen ten behoeve van de verbreiding van de kennis omtrent Suriname.

Aangezien de voorgeschoten gelden nog niet zijn terugbetaald is thans nog geen fonds in het leven geroepen, waaruit de kosten ter verbreiding van de kennis omtrent Suriname kunnen worden bestreden, maar het laat zich aanzien, dat dit tijdstip eenmaal zal aanbreken.

Een copie van de rolprent berust sedert Februari 1931 in het Koloniaal Instituut te Amsterdam, geschonken door baron Van Heemstra.

e. Fonds tot Herstel van de Kerkruine met daarbij behoorende Begraafplaatsen op de Joden Savanne in Suriname. Aanleiding tot de stichting was het volgende. Op 7 Januari 1927 hield Fred. 
Oudschans Dentz, op uitnoodiging van de Maatschappij der Nederlandsche Letterkunde te Leiden, een voordracht en koos als onderwerp: De kolonisatie van de Portugeesch Joodsche Natie in Suriname en de geschiedenis van de Joden Savanne.

Deze voordracht verscheen in druk bij Menno Herzberger te Amsterdam. Kort na de verschijning in Sept. was een 2de druk noodig. In het woord vooraf van den schrijver werd de mededeeling gedaan, dat er zich een commissie gevormd had tot herstel van den eenigen bouwval uit Suriname's verleden en om die te behouden voor verderen ondergang, $\mathrm{nl}$. de ruïne van de in 1685 door de Port. Joodsche Natie in Suriname gestichte Synagoge op de Joden Savanne, gelegen aan de Surinamerivier, met de daarbij behoorende begraafplaatsen.

Teneinde de commissie internationaal te maken had de heer Oudschans Dentz personen uit verschillende landen uitgenoodigd daarin zitting te nemen en behalve een aantal vooraanstaande personen, zoowel uit Joodsche als andere kringen in Nederland werd een subcommissie gevormd in Suriname, Engeland en de Vereenigde Staten van Noord-Amerika.

Prof. dr. J. L. Palache trad als voorzitter en de heer Oudschans Dentz als secretaris, beheerder van het te vormen fonds op. Van verschillende personen, en in de eerste plaats mogen Hare Majesteit de Koningin en de Koningin-Moeder worden genoemd alsmede van Joodsche kerkgenootschappen en instellingen ontving de beheerder bijdragen voor het fonds, maar het mocht niet gelukken, zelfs in Suriname niet, voldoende belangstelling te wekken, waardoor het fonds een zoodanige grootte kon bereiken, dat uitvoering der plannen mogelijk bleek. Na aftrek der gemaakte kosten is het fonds met de daarbij geboekte rente, tot ruim $f$ 850.gestegen. Het is soliede belegd.

Aangezien, vooral in Suriname tal van leden der commissie zijn overleden of vertrokken is reorganisatie dringend noodig en die zal ook worden ter hand genomen. De secretaris der commissie is in onderhandeling getreden met den directeur van Openbare Werken in Suriname om tot een nadere raming der herstel- en onderhoudskosten te komen.

f. Ondersteuningsfonds van de Vereeniging „Suriname”. Op de ledenvergadering van 20 Mei 1930 keurde de Vereeniging „Suriname” welke te Amsterdam gevestigd is een reglement goed van een Ondersteuningsfonds gevestigd aan het secretariaat der Vereeniging. Reinier Claeszenstraat 29. Dit reglement werd 1 Juni 1931 gewijzigd. 
Aanleiding tot de stichting van dit fonds was de slechte economische toestand van Suriname als gevolg van de aldaar heerschende werkloosheid, waardoor vele Surinaamsche jonge mannen en meisjes genoodzaakt waren hun geboortegrond te verlaten om elders een bestaan te zoeken.

Ondanks de waarschuwing van de Vereeniging zijn vele Surinamers naar Nederland gekomen en slechts aan enkelen mocht het gelukken een vaste dienstbetrekking te vinden. Velen zijn toen in Nederland in ernstige geldelijke moeilijkheden gekomen. En ofschoon het bestuur der Vereeniging „Suriname”, soms in samenwerking met het Burgerlijk Armbestuur en met Maatschappelijken Steun, enkelen heeft kunnen helpen, die geldelijken steun hebben verzocht, moesten toch velen worden afgewezen. Vandaar de oprichting van een Ondersteuningsfonds dat ten doel heeft steun te verleenen

$a$. aan de leden van de Vereeniging, zoowel voor henzelf als ten behoeve van hun echtgenooten en te hunnen laste zijnde kinderen.

$b$. aan Surinamers, die in Nederland zijnde, plotseling voor financieele moeilijkheden komen te staan.

$\mathrm{Bij}$ de oprichting van het Fonds, werd het batig slot groot $f 115,83$ van een gehouden Suriname-avond daarin gestort, terwijl als eerste gift Hare Majesteit de Koningin een bedrag van $f 300$ schonk.

Van de werking van dit Fonds kan uit den aard der zaak nog weinig worden medegedeeld.

g. Het Surinaamsche Steuncomité. Dit comité werd opgericht op 27 Juni 1931 met het doel in het bijzonder bestrijding der thans in Suriname heerschende werkloosheid en leniging der daaruit voortvloeiende nooden. Dit doel kan worden uitgebreid tot andere nooden der bevolking, wanneer in eene daartoe bijzonderlijk bijeengeroepen algemeene vergadering van het Comité met ten minste $2 / 3$ der uitgebrachte geldige stemmen daartoe besloten is.

Het Comité tracht het doel te bereiken door:

$a$. het geven van voorlichting en het verleenen van steun aan werkzoekenden, behoorende tot de bevolking van Suriname, wier eigen middelen daartoe ontoereikend zijn, een en ander ter verkrijging van een levensbestaan;

$b$. het verstrekken van voorschotten aan werkloozen en werkzoekenden, zooals aan hen, die zich op den kleinen landbouw willen toeleggen, die in de boschbedrijven werkzaam willen zijn, enzoovoort :

c. het verstrekken van voedsel aan behoeftige kinderen;

d. zoo noodig de aandacht van de Overheid te vestigen op toestan-

West-Indische Gids XV 
den op het gebied der werkloosheid - en eventueel op andere nooden - welke, naar het oordeel van het Comité, voorziening behoeven;

$e$. alle verdere wettige middelen, welke in den ruimsten zin des woords, bevorderlijk kunnen zijn aan het doel, hetzij direct of indirect.

De statuten van dit Comité werden den 28sten Juli 1931 vastgesteld, bij resolutie van 15 Aug. d.a.v. no. 2656 door den Gouverneur goedgekeurd en in het G.A.B. van 25 Augustus 1931 no. 71 opgenomen.

Het comité heeft zijn omvangrijke taak verdeeld en toevertrouwd aan vier subcomité's nl.: een voor de kindervoeding, een voor den klein-landbouw, een voor de klein-industrie en een voor de boschbedrijven.

H.M. de Koningin schonk het Comité een som van $f 1500$.

Behalve de vele giften in de fondsen van het Comité gestort door particulieren draagt het Bestuur van Suriname door een groote schenking bij aan de instandhouding terwijl een groote schenking van $f 3000$ van een dames-comité onder leiding van de echtgenoote van den gouverneur uit de opbrengst van een bazaar, niet onvermeld mag blijven.

In 1931 werd als landsbijdrage aan het S.S.C. $f 8000$ voor zijn werkzaamheden uitgekeerd. Dit bedrag werd in hoofdzaak uitgegeven voor steun aan de, bij den klein-landbouw geplaatste werkloozen.

Men kan dit Comité met het Nationaal Crisis Comité van Nederland vergelijken.

CURAÇAO.

Het Ondersteuningsfonds "Nederlandsche Antillen” is op 26 April 1913 gesticht terwijl het Curaçaosche Ondersteuningsfonds, in 1917 in het leven geroepen werd ter versterking van de middelen welke het eerstgenoemd fonds behoeft.

Alvorens over de stichting van beide fondsen de geschiedenis mede te deelen, ga de voorgeschiedenis vooraf, welke tot het jaar 1908 terugvoert.

Immers in dat jaar deed het bestuur van de Groep Nederlandsche Antillen van het Algemeen Nederlandsch Verbond een beroep op het volk van Nederland, gedagteekend 18 Sept. te Curaçao waarin werd gezegd:

Niet dan noode komen wij tot $\mathrm{U}$ !

Het volk van Curaçao, door droogten en misoogsten in de harde school der armoede groot geworden, zou ook thans Uwe hulp niet durven inroepen, zoo de nijpende nood niet daartoe dwong. 
De algemeene ellende onder de stads- en landbevolking, ten deele slechts gelenigd door regeeringshulp, kan alleen door particuliere ondersteuning der weinige gegoede burgers in de kolonie Curaçao niet worden verzacht, maar vraagt ook dringend de medewerking der meer gegoede bevolking in Nederland.

Duizenden Nederlandsche onderdanen, onmiddellijk en middellijk getroffen door de maatregelen van Venezuela, lijden gebrek en staan aan ontberingen bloot, die diep medelijden wekken.

Dat aan den vreeselijken toestand door het beleid onzer Regeering een einde zal komen, betwijfelen wij niet, maar de dagen en weken gaan voorbij en de ellende wordt steeds grooter. Helpt ons, stelt ons in staat om aan den grootsten nood het hoofd te bieden en het volk van Curaçao zal met dankbare erkentelijkheid zegenen zijne broeders in het verre Moederland.

Inmiddels was reeds door de vereeniging Oost en West een beweging op touw gezet om onze kolonie in haren nood te helpen en in samenwerking werden in overleg en onder toestemming van den gouverneur van Curaçao eendrachtig gelden ingezameld om de bevolking van dit gewest, dat door gebrek en hongersnood bedreigd werd, te helpen. Behalve door het bestuur van de Groep Ned. Antillen van het A.N.V. werd de beweging gesteund door de afgevaardigden dezer groep in het Hoofdbestuur, dr. J. Boeke en Luit. J. A. Snijders, maar evenzeer door de hoofdbesturen van de vereeniging Oost en West en het Alg. Ned. Verbond.

De nood op Curaçao was ontstaan door het geschil met Venezuela, waardoor de handel stil stond en duizenden armoede en gebrek leden, waarbij nog kwam de rupsenplaag waardoor het hoofdvoedsel, de kleine mais, op vele plaatsen was weggevreten. De offervaardigheid om het gebiedsdeel te helpen blijkt uit de lijst van verantwoording van ingekomen gelden ${ }^{1}$ ) bedragende $f 8.843,13^{1} / 2$, waaronder giften van de H.M. de Koningin, de Koningin-Moeder en Prins Hendrik van onderscheidenlijk 1000, 300 en 100 gulden. Uit dit bedrag werden de bewoners zoowel van Curaçao als die van Aruba en Bonaire geholpen. In de bestuursvergadering van de groep Ned. Antillen van het A.N.V. op 15 Mei besloot men een ondersteuningsfonds op te richten ${ }^{2}$ ) dat als basis zou hebben de gelden, die te laat waren ingekomen om nog gedurende het geschil met Venezuela te worden uitgedeeld. Doch dit zou nog tot 1913 duren.

Andermaal, in 1912 werd een beroep gedaan voor de noodlijdenden in de kolonie Curaçao, door een Comité tot leniging van

$\left.{ }^{1}\right)$ Men zie de verantwoording der gelden in Neerlandia van April 1909, blz. 83.

2) Zie Neerlandia Juli 1909, blz. 167.

West-Indische Gids XV 
den nood, waarin de dagelijksche besturen van het A.N.V. (met de vertegenwoordigers van de groep) en de vereeniging Oost en West zitting hadden. De oproep was gedagteekend uit Leiden in Augustus van dat jaar. Vooral de door de natuur zoo zeer misdeelde eilanden Bonaire en Aruba waren geteisterd, toen de regen uitbleef, alle middelen van bestaan waren te niet gegaan, de oogst totaal was mislukt, de dieren stierven, de bodem een dorre woestenij was geworden, scheurbuik en dysenterie hare slachtoffers maakten. Wederom ging het Koninklijk Huis voor met giften van 500, 500 en 200 gulden van de Koningin, de Koningin-Moeder en den Prins (terwijl H.M. nog $f 1000$ vóór de oproeping naar Curaçao gezonden had). Er werd totaal ontvangen een som van $\left.f 33.901,43^{1} / 2^{1}\right)$. De verantwoording der bestede gelden voor de noodlijdenden op de Benedenwindsche eilanden wees een bedrag van $f 20.790$ aan ${ }^{2}$ ).

In een vergadering ten gouvernementshuize van de groep Ned. Antillen op 25 April 1913 werd besloten een „Ondersteuningsfonds Nederlandsche Antillen" te stichten ${ }^{3}$ ), waarin de overgebleven gelden werden gestort. In de statuten daarvan lezen wij, dat het ondersteuningsfonds Nederlandsche Antillen op den 26sten April 1913 is gesticht met een aanvangskapitaal, groot $f 18550,30$. verkregen uit de overgebleven gelden, die in het jaar 1912 zijn ontvangen voor de noodlijdenden op Curaçao, Aruba en Bonaire. Verder, dat het doel dezer Stichting is, om ingeval van langdurige droogte, mislukking van de oogst of andere bijzondere omstandigneden groot gebrek onder de bevolking heerscht, na gepleegd overleg met den Gouverneur en het Bestuur van de groep Antillen, van het A.N.V. uit de gekweekte rente en zoo noodig uit het kapitaal, uitkeeringen te doen aan de noodlijdenden.

Het beheer van het fonds wordt opgedragen aan een commissie van zes leden, zoo mogelijk bestaande uit vier leden van de groep Nederlandsche Antillen van het A.N.V. en twee leden van de Vereeniging Oost en West, die om de vijf jaar door den Gouverneur der kolonie, in overleg met het Bestuur van de groep Nederlandsche Antillen worden gekozen.

Voor de eerste maal werd het beheer van het fonds aan de heeren H. J. Th. Boomgaart, Ed. S. Lansberg, Jules L. Penha, W.

1) Men zie de verantwoording in Neerlandia van October $1912 \mathrm{blz}$. 239, November 1912, blz. 259, December 1912, blz. 278, Mei 1913, blz. 113 en Juli 1913, blz. 159.

2) Men zie de Rekening en Verantwoording in Neerlandia van Februari 1913 , blz. 41.

s) Zie Neerlandia Juni 1913, blz. 137. 
van den Brink, H. Ferguson en L. van der Veen Zeppenveldt opgedragen. De commissie van beheer brengt in Februari van ieder jaar aan den Gouverneur en aan het bestuur van de groep Nederlandsche Antillen van het A.N.V. verslag uit omtrent den toestand van het fonds.

De statuten werden op 3 Juni 1913 vastgesteld en goedgekeurd bij Gouvernementsbeschikking van 2 October 1913 no. 825. Zij werden in de Boletin Comercial van Maandag 6 October 1913 no. 1577 bekend gemaakt.

In het Verslag van Bestuur en Staat over 1931 staat vermeldt, dat het Fonds eind $1931 f 24.596$ groot was.

Doch de langdurige droogte bleef Curaçao teisteren. Ook in 1914. Zooveel mogelijk werd van bestuurswege getracht in den toestand te voorzien door het ondernemen van werken van bijstand, terwijl ook van de zijde van particulieren en door het Ondersteuningsfonds "Nederlandsche Antillen” al het mogelijke werd gedaan tot leniging van de armoede. Maar versterking van de beschikbare middelen werd dringend noodig geacht. Met het oog hierop bevorderde de Minister van Koloniën de totstandkoming van een commissie, ten doel hebbend gelden bijeen te brengen tot versterking van voornoemd fonds.

Als voorzitter werd uitgenoodigd op te treden $\mathrm{jhr}$. J. O. de Jong van Beek en Donk, terwijl de volgende heeren zitting namen: J. W. van Aalst, prof. dr. J. Boeke, G. P. van Hecking Colenbrander, mr. L. M. Rollin Couquerque, mr. C. S. Gorsira, G. G. D. d'Aumale baron van Hardenbroek, J. Janse, dr. J. Krause, C. Statius Muller, J. Poiesz, C. M. van Rijn, J. van Vollenhoven, A. C. A. van Vuuren. Onder leiding van den Minister van Koloniën kwamen deze heeren op 26 Januari 1915 bijeen om maatregelen te beramen. De benoeming dezer leden had bij beschikking van 25 Januari 1915 afd. B. n. 48 plaats, met uitzondering van pater Poiesz, in wiens plaats benoemd werd $\mathrm{mr}$. C. W. Th. van den Brandhof.

De statuten van de stichting „Het Curaçaosch Ondersteuningsfonds" waren gedagteekend 15 November 1917. Zij werden opgenomen in de Ned. Staatscourant van 28 December 1917 no. 302. Het Huishoudelijk reglement, op 5 Maart 1918 goedgekeurd, verscheen in de Ned. Staatscourant van 24 April 1918 no. 95 .

Volgens het Verslag van Bestuur en Staat over 1930 (Hoofdstuk G.: Armenzorg) bedroeg het kapitaal $f 156.001,50$. Uitkeeringen 
hebben in lange jaren niet plaats gehad. Het kapitaal groeit voortdurend door rente aan.

In die statuten lezen wij, dat de Stichting ten doel heeft: 1ste om te beheeren gelden, welke reeds zijn of nog zullen worden bijeengebracht ter versterking van de middelen, welke het „Ondersteuningsfonds Nederlandsche Antillen", gevestigd te Willemstan op het eiland Curaçao, behoeft tot het, overeenkomstig zijne statuten, doen van uitkeeringen aan noodlijdenden, wanneer er ten gevolge van langdurige droogte, mislukking van den oogst of andere bijzondere omstandigheden, groot gebrek onder de bevolking van de kolonie Curaçao heerscht, zijnde hiervoor bij het verlijden dezer akte beschikbaar gesteld een stamkapitaal van honderd gulden.

2 de. om telkens, wanneer daartoe aanleiding ontstaat, maatregelen te treffen, teneinde hare middelen aan te vullen en

3de. om, wanneer daartoe, na gehouden onderzoek, termen worden gevonden, ondersteuningen te verleenen uit de door haar beheerde gelden, aan de inwoners van de kolonie Curaçao, die zich tot het verkrijgen daarvan bij het Stichtingsbestuur mochten aanmelden.

In een huishoudelijk reglement is een regeling opgenomen van het beheer der Stichtingsgelden, van de overmaking van gelden aan het „Ondersteuningsfonds Nederlandsche Antillen" en van het toestaan van ondersteuningen aan inwoners van de kolonie Curaçao.

De Stichting wordt door een Bestuur van tenminste 5 personen beheerd, die de Minister van Koloniën aanwijst. Bij ontbinding der Stichting, welke de Minister van Koloniën moet goedkeuren, wordt het na de likwidatie overblijvende batig saldo ter beschikking van den Minister van Koloniën gesteld om te worden aangewend in het belang van de kolonie Curaçao.

(Wordt vervolgd.) 